\title{
THE SUNDAY SCHOOL IN INDIA
}

\author{
BY EDWARD A. ANNETT
}

I

Sunday schools in India vary greatly in character and in composition. They are of all types from the large school with a fair attempt at grading, down to the most primitive of gatherings where a few nondescript children of all ages recite verses under the care of a single teacher. Sunday schools spring up in all sorts of places and in all kinds of ways. In some places they receive considerable recognition and encouragement, while in others they languish in obscurity. They may be roughly divided, however, into four main classes.

(1) There is first of all the Sunday school that approaches most nearly to the type of those in western lands. It is usually held in connexion with a particular congregation, and in many cases possesses teachers whose service is purely voluntary. The children of the Christian community compose the school, with occasionally a sprinkling of adults. There may be a class or two of non-Christians, but that is not usual. Ordinarily there is a superintendent, who finds it a constant struggle to supply the clásses with teachers. In the larger Sunday schools the children mostly come from the local boarding schools, and in those cases the teachers are largely drawn from the teaching staff of the same institutions.

(2) The next type of Sunday school is that held in connexion with the mission day school. Nearly half a million boys and girls of the non-Christian communities attend the various grades of day schools that are run by the missionary societies. A large proportion of these 
attend Sunday schools, which range from the organized school connected with the college or high school down to that held in the village primary school where children of all ages are gathered in a single class. In such Sunday schools the scholars are almost entirely non-Christiain, the grading follows that of the day school, and the teachers work with the same classes as through the week. There are Sunday schools where it is found possible to enlist the services of other Christians as teachers, and in occasional instances the older scholars of a local boarding school are allowed to help the day school teachers in this work.

In this class of Sunday school, as in those previously mentioned, the scholars have a considerable amount of actual Bible knowledge, since they have a Scripture lesson every day of the week. The Sunday school is in danger with them of being considered merty as a prolongation of the day school, especially when the classes are held in the same room as those of the day school, are taught by the same teachers and, as in many places, use the same lessons. There are not a few schools where the International Uniform Sunday School Lesson is taught on Monday, on Tuesday, and each day to Friday, and then it appears again as the subject for Sunday, by which time it may be believed that there is some measure of acquaintance with it, even if relish be lacking.

The majority of Indian Sunday schools belong to one or other of these two categories, and for practical purposes they may be considered together, for in each case children are dealt with who are under regular Bible instruction and Christian influence all the week through. One of the principal problems connected with them lies in the relation of the Sunday school to the day school. The Sunday school shares with the day school in the religious instruction of the young, in the imparting of Christian and Biblical knowledge. This instruction is directly related to the moral problems which concern our attitude to our fellowmen, to social and national questions, and to the relations 
between Christianity and the religious philosophies of the land. But there is another whole department with which Christian nuriure is concerned-that of worship and inspiration. 'The function of worship is an indispensable religious educational force. It is the conscious relation of self to the presence and purpose of God. It nceds an atmosphere of quiet and serious reverence for which the associations of the day of rest are a real help, and which is not easily secured in the daily classroom. Here lies the opportunity of the Sunday school.

Now of course this demands that the Sunday school shall be more than a mere time-filler or makeshift. It claims that it shall be a place where the child may have an experience in which he feels God to be near and real. Such experiences are ncver forgotten. They introduce the child to a new world. They awaken within him the consciousness of the presence of God. They weave into the fibres of his being new elements that are among the most powerful in life.

It is evident, too, that there should be careful correlation of the syllabus of the day school with that of the Sunciay school. It is a simple way out of the difficulty to accept a Sunday school syllabus that is used in western lands, with its wealth of lesson-helps and pictures. But the simplest way is not always the best way. It is conceivable that the same syllabus may do for America and England and for India, but in a matter of such importance nothing should be taken for granted. The syllabus used must meet the needs of the children we are dealing with. Account must be taken of the fact that these children have a great deal more of systematic Bible teaching during the week than most children in the West, and also thai they live their lives in an environment that is antagonistic to Christian ideals in a measure and in a manner unknown in western lands. The work done in the religious cducation of the children of our schools has been good work, but the results have been, nevertheless, in many cases 
disappointing. We are conscious that we have not succeeded up to the measure of our expectations, and we cannot be satisfied with any syllabus, however widely used elsewhere, that does not meet our particular needs.

(3) The third type of Sunday school is that found in the mass movement areas. Here large numbers of children, not to speak of adults, are in our care. They are for the most part very ignorant, for few of them attend a day school regularly. They have no normal Christian community around them, and are naturally influenced tremendously by the old habits of the caste. But they are ours to teach and train, there is no anti-Christian bias to contend with, and they will be at our disposal for a number of years. Under present conditions, however, with great numbers of them the religious instruction imparted is far from regular. It is true that each year increasing numbers of teachers are being placed out in new schools by the missions concerned. But the districts are large and the people live for the most part in scattered hamlets and many are dependent on the visits of an itinerant evangelist-teacher. Difficulties in regularity are found even with the most conscientious of those who fill this hard position;- and in some cases the children get far less than a weekly Bible lesson. The same teacher may have a dozen different hamlets to attend to, and the personal touch is apt to be slight. It is evident that the term Sunday school will have rather a different connotation here than in a settled station, and yet in point of importance the work yields to none. For it is, beyond question, the main instrument in the Christianizing of these willing masses. The syllabus will certainly be much simpler in its elements than that suited to the average Sunday school, its division into grades will be made on a different plan, its scope will be less pretentious, its method will be much slower. The very difficulties of the work, however, make necessary the utmost care and wisdom in framing the course of lessons to be taught. 
(4) The fourth type of Sunday school may be called, for lack of a better term, the evangelistic Sunday school. In every part of the country a beginning at least has been made at the task of holding Sunday schools among children who are not touched by other Christian influences. This constitutes the best and easiest method of the evangelization of India by the Indian Church. The accessibility of the children of India is phenomenal. There seems to be no limit whatever to the number that may be gathered in Sunday schools except the number and the fitness of the teachers. Given a teacher who is even moderately interesting and an audience is assured. Not only are the children of the depressed or poorer classes obtainable, but in many parts of the country it is found that Sunday schools for Brahmin and other high caste scholars and even for Mohammedan children may be maintained. Some examples will illustrate this.

In one town eighty voluntary workers, mostly high school students, go out in bands to appointed places and hold Sunday schools in the open air. They have no buildings and no appurtenances save what they can carry in their hands, and yet they have on their rolls 1700 scholars with an average attendance almost as large. These children are quite untouched by any other Christian agency. In another large city the teachers of the Sunday school formed themselves into a missionary association and opened a number of Sunday schools in the slums of the neighbourhood. Each school has an experienced leader and several helpers, and in this way they have multiplied their Sunday school attendance by ten, and at the same time have awakened a healthy desire for service on the part of the congregation.

In one town in Northern India there were three Sunday schools in existence for Mohammedans run by the members of a comparatively small church. Sunday schools may be found in Hindu day school buildings, and one at least is held in a Hindu temple. In one town in South India the 
students of the Christian college for a small consideration are allowed the use of private Hindu schools on Sunday afternoons, and the Hindu teachers gather the children together for Sunday school. In another place in South India a missionary secured entrance into a Hindu day school where the managers felt that the Sunday school influence would help them in the difficult matter of the children's morals. 'Does Sunday school make children better?' they asked, 'for we cannot manage our boys, they are so naughty.' The results were so good that other schools of the same kind extended invitations until eventually fifty-nine voluntary workers were conducting one hundred Bible classes weekly in Hindu day schools.

In various places mothers who cannot go far afield hold Sunday school on their own verandah or in their own homes. A most interesting Sunday school for Moslem children filled to overflowing the two rooms of the house of a convert from Mohammedanism. The commodious Sunday school premises near by were impracticable owing to local Mohammedan feeling.

The syllabus used in these evangelistic Sunday schools will, of course, be different again from those suitable for the other types of Sunday school already mentioned. Here we have children not only ignorant, in all probability, of Christian truth, but in our hands for only a limited time. Whatever instruction is given must be given in as small compass as is consonant with efficiency. Concentration must be made on the things that are essential. In many schools of this type a course of lessons is being used which attempts to cover in the space of a single year all that is necessary for a child to know in order intelligently to accept Christ as a personal Saviour.

\section{II}

The existing Sunday schools of the Indian empire of all these types are worked by a force of between thirty 
and forty thousand teachers, of whom only a small proportion are purely voluntary workers. The number of these, however, is increasing year by year; this is a most hopeful sign, for the strength of the Sunday school movement lies in its voluntary nature. Incidentally, for her own sake the Indian Church needs the Sunday school as a means of development in service for her own members. To become thoroughly indigenous the Indian Church must take the initiative in the propagation of the Gospel; owing to the circumstances of the past she has had little opportunity of learning the joy and the duty of voluntary service and that element in her character is greatly in need of strengthening. The Sunday school has rightly been termed the workshop of the Church, the place where its members may learn to serve. Capable as it is of indefinite expansion, the Sunday school has room for all classes of workers and with its elasticity of form and method no willing soul need be refused work. Let the Indian Church catch the vision of the glory of unstinted, voluntary service for the Kingdom and the question of the supply of teachers for this work will quickly be solved. The material is there already. The present force of teachers might certainly be quadrupled, at the very least, and thus provide for a tremendous increase in the directly evangelistic work of the Church.

Intimately connected with the question of the supply of teachers for the Sunday schools, and even more urgent, is that of training the teachers for their work. All the problems of the Sunday school eventually resolve themselves into this one problem, the personality of the teacher. It is an old fallacy that takes a lot of killing that teachers are born and not made. There is a modicum of truth in it, of course, but it is one of the most ingenious excuses for idleness ever invented. If one may take the liberty of varying a remark lately made by $\mathrm{Mr}$ Chesterton, it is not that the making of teachers has been tried and found wanting, but that it has been found difficult and not tried. 
The teachers need training because of the difficulty of their task. We have too often in the past made the fatal mistake of imagining that the teaching of religion to children is an easy thing. It is not beyond our powers, but it demands that those powers be trained for use. With the increasing knowledge of the child-mind the conception of religious education has widened. It is seen to be education in earnest, not the mere acceptance of a theological system or the learning by rote of a prescribed catechism or sets of lessons, however important these may be. It is rather, as the word implies, the drawing out of the religious nature, the clarifying and strengthening of religious ideas and ideals, the understanding of the nature of sin, the enriching of the sense of God, that through these the scholars may be drawn to Christ. Religious education, therefore, is not to be imposed from without, but to be developed from within. The poorer grades of teachers may but dimly grasp the underlying reasons for these fundamental principles of education; but they can be taught how to work in conformity with them. The introduction of a new syllabus of lessons on sound lines makes training still more urgent. A good syllabus will lose half its effectiveness unless the teachers are trained to use it aright.

Our existing teachers need training. Some years of expcrience in discussing the problems of the Sunday school with them has impressed the fact that they are conscious of their need of definite help for their work, and that many of them are willing to make sacrifices in order to obtain it. Sympathy is certainly due to those who have to teach the Bible to children for five or six days a week, with no special training for that work, with a very meagre conception of the goal they are to aim for and with less idea of how they are to reach it. They may be, in some cases, men and women of poor calibre, but they are the best teachers that some children will ever have. With those especially who work in the villages and the slums, their influence is probably the only direct influence for God that will ever 
touch the lives of their scholars. Work that is careless, ignorant or faithless will not only fail of the fruit we desire but is likely to yield a crop of results antagonistic to vital Christianity. A child may become 'gospel-hardened' even more quickly than an adult. The material indeed is plastic, but for that reason impressions of some sort it must receive, and if the gospel of Christ fails to awaken a glad response and to find its natural welcome the child is likely to grow up to be a man who has no use for it.

Certainly the teachers will not do the best work they are capable of unless they have sufficient conception of the nature of the child to enable them to use the powers that God has placed at their disposal within the child. Nor will they do justice to the Bible message unless they have some idea of the best method of presenting it to their scholars. The endless memorizing, ill-done and worse reviewed, that is the only method of not a few, varied occasionally by moralizing that is quite beyond the sphere of the child's interest, is scarcely calculated to transform character and win the heart; but little blame can be laid upon the teacher who has never had the opportunity of learning a better way. The onus of responsibility lies upon the missions and the churches to see that such opportunity is given, whatever it may cost. In many parts of the country missions are encouraging their workers to take the India Sunday School Union Teacher Training Course, and very good reports have been received of the value of this study. One large mission has arranged for every worker in its field to study one book of the course each year and to take an official examination on the subject. Another mission brings in its workers of all grades for a month's training every year, in which increasing emphasis is being laid upon their training for Bible teaching. Under normal conditions the most practical training will be given in connexion with the weekly preparation class where each new principle taught may be definitely linked on to practice in the regular work of the Sunday school. 
This will not be possible, of course, with those who are working at a distance from the centre, but those near at hand may be encouraged to avail themselves of such a class.

Turning from the existing workers to prospective workers, we naturally think of the young people in our boarding schools and congregations. Arriving at the age when the altruistic instinct is at its strength they are ready subjects for an appeal for Christian service. They will respond with avidity to the call to teach, and they are still young enough to learn with eagerness the best methods of working. This is seen in the success of the primary departments that are springing up in various parts of the country. But if these young people are to become really useful workers it is essential that they attend a class for training and for the due preparation of the lesson. When rightly conducted such a class has three important uses. It is the best kind of Bible class since the general study of the selected passage of Scripture has a practical purpose in view which appeals to the young teachers and challenges their attention. It prepares the lesson for presentation to the class on a regular plan, and thus the right handling of the Bible for the young tends to become habitual. And then, in the hands of a wise leader, it constitutes a very effective method of training, because the discussion of the presentation of the lesson affords constant opportunity for the natural unfolding of the laws of the child-mind and of religious pedagogy. One hour a week spent thus over the Bible lesson, considering it in connexion with the child and his temptations, seeing where the Bible touches the fundamental needs of childhood, would make all the difference both to the Sunday school and to the teachers themselves.

Another important branch of training for Sunday school work should be that of the students in the theological seminaries. The pastors of the future must be thoroughly fitted to co-operate with and train those who 
are teaching in their Sunday schools. For this each theological seminary needs to have the subject definitely taught as a part of the curriculum, with schools where the students may put into practice under regular supervision the principles they have learnt. The pastor in India has as much need for this as for ministerial training, and if Sunday school work is an extra in the seminary it is likely to be regarded as an extra in the pastorate.

This leads to the realization of another urgent need. If the existing teachers are to have real help given them for their work, if the young people are to be fitted for service, if the pastors are to receive adequate preparation for their labour among the young, leaders must be trained. Men and women must be found who can master the principles of the subject sufficiently to train others satisfactorily. Each field should have one man at least who understands the business of religious education in a systematic way. Each normal training institution and especially each theological seminary ought to have one person able to teach the subject.

The training for these leaders will include courses in child study and in the methods of religious education. The supreme value of the concrete in religious teaching must be understood and practical training in story telling given. Rudimentary instruction at least must be given in the art of handling children and of securing reverence and a worshipful atmosphere. Conversion and the laws of growth of religion in the soul, the principles of home training and the moral importance of play, the value of discipline and punishment and an introduction to general pyschology would be subjects essential for the due equipment of a trainer of teachers. The Bible, too, would be studied from the standpoint of the child. Such a mastery of its narratives should be attained as will make them live in the imagination of the teacher and rescue the personalities of the Bible from hazy unreality, introducing them to the teacher as men with living messages. The changing appeal 
of the Bible stories for children in the various stages of development would be recognized. Above all, these leaders should be enabled to understand Christ so that He may be portrayed to the children in all His ineffable charm.

This points to the ultimate necessity of a central training institution where such leaders may be thoroughly fitted for their life-work. The difficulties that are inseparable from the inception of such an institution are considerable but they are not insuperable; and it is certain that something of the kind will eventually be essential if the teachers in our Indian churches are to make the best of their important service. Until we have Indians thoroughly trained in the moral and religious aspects of child psychology we can hardly expect to have tlat guidance on matters connected with religious education that can only come from sons of the soil. The soul of the Indian child has been almost a closed book up to the present. Not a volume has yet appeared dealing with child nature in the East, scarcely a pamphlet. And an understanding of this subject is perhaps more urgent than anything else to-day, for there is not a problem of religion or morals in India that is not directly affected by it. The rich and growing literature in the West throws much light upon the East, but the differences between Oriental and Occidental are too real to be disregarded. The great fundamental principles of child nature all the world over are the same, and that provides the common ground for research, but the modifications arising from centuries of Hindu environment have produced types of humanity sufficiently distinct to necessitate thorough investigation and corresponding adaptation of methods. The discoveries of American and European scholars in this sphere provide the stimulus and suggest the lines of advance for students in the East; but where shall these students be found? Surely we may expect to discover them among those who have been trained to think accurately and scientifically on these subjects. 
A small beginning has been made in training of such leaders in two schools, each of one month's duration, held at Meerut in North India and Coonoor in South India respectively. Sixteen students attended each of these schools, representing altogether rather more than a dozen societies; the results of these tentative gatherings give reason for enthusiastic hope for the development of similar work in days to come.

In conclusion, may it not be urged that these demands are surely reasonable when the importance and magnitude of the work is considered? It is certain that we shall never make such real progress in this field until we train the teachers for their service. Without that specific training the loss incurred is enormous and, to some extent, irremediable. No amount of reform in the methods of the Sunday school or in the character of the syllabus will make up for failure in this direction. For the teacher himself is the crux of the whole problem of religious education.

Edward A. ANNetT 